\title{
Sosyal Bilgiler Odaklı Akademik Risk Alma Ölçeğinin (SOARAÖ) Geliştirilmesi: Geçerlik ve Güvenirlik Çalışması
}

\author{
Arş. Gör. Melehat GEZER* \\ Dicle Üniversitesi, Ziya Gökalp Eğitim Fakültesi, Sur / Diyarbakır / Türkiye \\ Arş. Gör. Mustafa İLHAN \\ Dicle Üniversitesi, Ziya Gökalp Eğitim Fakültesi, Sur / Diyarbakır / Türkiye \\ Prof. Dr. İbrahim Fevzi ŞAHİN \\ Atatürk Üniversitesi, Kazım Karabekir Eğitim Fakültesi, Erzurum / Türkiye
}

\section{Özet}

$\mathrm{Bu}$ araştırmada öğrencilerin sosyal bilgiler odaklı akademik risk alma davranışlarını geçerli ve güvenilir olarak ölçmeye olanak tanıyacak bir ölçme aracının geliştirilmesi amaçlanmaktadır. Araştırma, 2013-2014 Eğitim-Öğretim Yılı Güz Dönemi'nde Diyarbakır ve İzmir illerinde toplam 474 ortaokul öğrencisi üzerinde yürütülmüştür. Araştırmada, ölçeğin kapsam ve görünüş geçerliği için uzman görüşüne başvurulmuş, yapı geçerliği için Açımlayıcı Faktör Analizi (AFA) ve Doğrulayıcı Faktör Analizi (DFA) uygulanmıştır. AFA sonucunda, toplam varyansın \% * Sorumlu Yazar. Tel: +90 $5327981714 \quad$ E-posta: melahatgezer@gmail.com 
33.86'sını açıklayan, 21 madde ve iki faktörden oluşan bir yapı elde edilmiştir. Ortaya çıkan faktörler Akademik Risk Almaya Yaklaşma (ARAY) ve Akademik Risk Almaktan Kaçınma (ARAK) olarak adlandırılmıştır. DFA'dan elde edilen bulgular, SOARAÖ’ye ilişkin 21 madde ve iki faktörlü yapının yeterli uyum indekslerine sahip olduğunu göstermiştir. ARAY ve ARAK alt ölçeklerinin güvenirliği iç tutarlılık yöntemiyle incelenmiş ve hesaplanan güvenirlik katsayılarının kabul edilebilir sınırlar içerisinde yer aldığı belirlenmiştir. Madde analizinden elde edilen bulgular, ölçekte yer alan maddelerin tamamının ayırt edici olduğunu göstermiştir. Bu bulgulara dayanarak, ölçeğin öğrencilerin sosyal bilgiler odaklı akademik risk alma davranışlarını ölçmek amacıyla kullanılabilecek geçerli ve güvenilir bir ölçme aracı olduğu söylenebilir.

Anahtar Kelimeler: Akademik risk alma; Sosyal bilgiler odaklı akademik risk alma ölçeği; Geçerlik; Güvenirlik.

\title{
Development of Social Studies Oriented Academic Risk Taking Scale: Validity and Reliability Study
}

\begin{abstract}
The present study aims to develop a valid and reliable instrument for measuring students' social studies oriented academic risk taking behaviors. The participants were 474 secondary school students studying in Diyarbakır and Izmir 2013-2014 Education Year Fall Semester. Expert opinion was consulted with regard to the scale's content and face validity. Exploratory Factor Analysis (EFA) and Confirmatory Factor Analysis (CFA) were performed in order to measure the scale's construct validity. As a result of EFA, a 21-item and a two-factor structure, which explains $33.86 \%$ of the total variance was obtained. The emerging factors were named as the approach to taking academic risk, and the avoidance from taking academic risk. The findings obtained CFA indicated that the 21 items and two-factor structure related to social studies oriented academic risk taking scale have satisfactory goodness of fit indices. The scale's reliability coefficients were calculated by means of internal consistency method. As a result of reliability analysis, it was determined that reliability coefficients were within acceptable limits. The findings of the item analyses showed that all of the items in the scale were discriminatory. In light of these findings it
\end{abstract}


could be argued that the scale is reliable and valid and can be used in order to test students' social studies oriented academic risk taking behavior.

Keywords: Academic risk taking; Social studies-oriented academic risk taking scale; Reliability; Validity.

\section{Extended Summary}

\section{Purpose}

The aim of this research was to develop a measurement tool for determining students' social studies-oriented academic risk taking behaviors and also to examine the psychometric properties of the scale.

\section{Methods}

The participants were 474 secondary school students studying in Diyarbakır and İzmir in 2013-2014 academic year first semester. Expert opinion was consulted with regard to the scale's content and face validity. Exploratory Factor Analysis (EFA) and Confirmatory Factor Analysis (CFA) were performed in order to measure the scale's construct validity. For criterion related validity, the correlation between students' scores obtained from the Social Studies-Oriented Academic Risk Taking Scale (SSOARTS) and social studies achievement scores were calculated. Students' previous year' GPA scores of social studies were considered as social studies achievement scores. The reliability of the SSOARTS was tested through internal consistency coefficients. The item discrimination of the SSOARTS was calculated through the corrected item total correlation and a comparison between the top and bottom $27 \%$ groups. The validity and reliability analyses were carried out with SPSS 20.0 and AMOS 20.0. 


\section{Results}

According to the first EFA results, a two-factor structure explaining $32.21 \%$ of total variance emerged. Since the factor load of item 3 was below .30, this item was excluded from the instrument. After removing this item, EFA was performed again and also, a two-factor structure explaining $33.86 \%$ of total variance emerged. Taking content and theoretical background into account, the first factor was called as the approach to taking academic risk, and the second factor was the avoidance from taking academic risk. The approach to taking academic risk subscale comprised 16 items and explained $23.11 \%$ of total variance. The factor loads of the items in this subscale varied between .35 and .67. The avoidance from taking academic risk subscale comprised 5 items and explained $10.76 \%$ of total variance. The factor loads of the items in the avoidance from taking academic risk subscale varied between .51 and .70 . In order to understand whether all 21 items and a two-factor structure provide satisfactory goodness of fit indices and to show further evidence for construct validity, CFA was performed. The CFA findings have shown that the scale has adequate goodness of fit indices $\left[\chi^{2} / \mathrm{sd}=2.44, \mathrm{GFI}=.91, \mathrm{AGFI}=.89, \mathrm{CFI}=.93, \mathrm{NFI}=.89, \mathrm{TLI}=92\right.$, $\mathrm{IFI}=.93, \mathrm{RMSEA}=.058, \mathrm{SRMR}=.054, \mathrm{PNFI}=.79$ and PGFI=.74]. According to concurrent validity results, there is a positive relationship between the academic risk taking behavior and social studies achievement $[\mathrm{n}=474, \mathrm{r}=.21, \mathrm{p}<.001]$. These findings have been regarded as proof that SSOARTS has concurrent validity. The reliability analysis showed that the internal consistency coefficients were $.81, .68, .78$ for the approach to taking academic risk, and the avoidance from taking 
academic risk subscales and the overall scale respectively. In order to identify discriminatory and predictive power of the items, corrected-item total correlations were calculated and both top and bottom 27 $\%$ of groups were compared. Pearson Product Moment Correlation was used to determine corrected-item total correlation. To compare both top and bottom $27 \%$ of groups, independent-samples $t$ test was performed. In item analysis, it was found out that item-total correlations varied between .24 and .55 and differences between both top and bottom $27 \%$ of groups were significant for all items.

\section{Discussion and Conclusion}

In this research, the findings from statistical analyses of psychometric characteristics of the SSOARTS revealed that the scale can be used as a valid and reliable instrument to measure students' social studies oriented academic risk taking behavior. As a result of the present study which aims to contribute to the literature with the SSOARTS, it can be argued that an instrument which has satisfactory psychometric characteristics to measure students' social studies oriented academic risk taking behavior has been developed. In addition, due to the fact that the present study was carried out with merely secondary school students, it might be implied that the SSOARTS is an instrument whose validity has been checked only with secondary school students. In this respect, future studies should check reliability and validity of the scale with different samples.

Within the scope of the concurrent validity analysis of SSOARTS, the correlation between SSOARTS and social studies achie- 
vement scores was calculated. The findings obtained from the correlation analysis show that the scale has satisfactory concurrent validity. A review of literature on academic risk taking behavior suggests that students' academic risk taking behaviors have an influence on their study skills, positive and negative perfectionism, problem solving skills, academic expectations stress. Accordingly, further studies could be conducted on the correlation between the SSOARTS and study skills, positive and negative perfectionism, problem solving skills and academic expectations stress. Hopefully, such studies will also make great contributions to the extent to which the SSOARTS measure what is intended.

\section{Giriş}

Öğrenme süreci, öğrenci için belirsizlikler içerir (Byrnes, 1998). Çünkü öğrenci, öğrenme sürecinde aldığı kararların ve gösterdiği çabanın nasıl sonuçlanacağı hakkında net bir bilgiye sahip değildir. Bir probleme yönelik olarak önerdiği çözümlerin ya da bir konu hakkında ileri sürdüğü fikirlerin doğru olup olmadığını tam olarak bilmemesi, öğrenci için bir belirsizlik oluşturur. İşte bu belirsizlik, öğrencinin risk almasını gerektirmektedir (Byrnes, 1998; Robinson, 2011). Öğrencinin öğrenme ortamında risk alması, akademik risk alma davranışı olarak nitelendirilmektedir (Beghetto, 2009).

Risk almanın tanımı konusunda araştırmacılar arasında tam bir görüş birliği olmaması (Yıldırım, Tay ve Ateş, 2007), akademik risk alma davranışının tanımının yapılmasını güçleştirmektedir. Bu durum, farklı araştırmacıların akademik risk alma davranışını değişik biçim- 
lerde tanımlamasına neden olmuştur. Strum (1971) akademik risk almayı, ileri sürülen fikirlerin ve önerilen çözümlerin olumsuz sonuçlanma ihtimali bulunsa bile sinıf ortamında herhangi bir konu ya da soru ile ilgili olarak tahminde bulunma eğilimi, şeklinde ifade etmiştir. Korkmaz'a (2002) göre, akademik risk alma davranışı öğrencilerin öğrenme ortamında karşılaştıkları güçlüklerle mücadele etmedeki cesaretini ve istekliliği/isteksizliğini yansıtmaktadır. Beghetto (2009), akademik risk alma davranışını, doğruluğundan emin olunmayan fikirleri paylaşma, soru sorma, yeni ve alternatif çözüm yolları deneme konusunda istekli olma şeklinde ifade etmektedir. Taylor (2010) akademik risk alma davranışını, belirli bir düzeyde belirsizlik içeren ancak öğrenmeyi destekleyen kararlar alma, olarak tanımlamaktadır. Robinson’a (2011) göre, akademik risk alma davranışı, bir öğrenme eylemine katılmanın bilinen ve bilinemeyen sonuçlarını değerlendirmeyi ve olası sonuçlarını düşünerek öğrenme sürecine katılma konusunda karar vermeyi içermektedir. Skaar (2009), akademik risk almay1, zorlu ve aşina olunmayan akademik görevleri tercih etme, olarak tanımlamaktadır. Clifford (1991) ise, akademik risk alma davranışını, Güç İşlemleri Tercih Etme Eğilimi (GITTE), Başarısızlık Sonrası Olumsuzluk Eğilimi (BSOE) ve Başarısızlık Sonrası Toparlanma Eğilimi (BSTE) boyutlarından meydana gelen bir yapı, olarak açıklamıştır. Clifford'a (1988) göre, akademik risk alma davranışı, seçme şansı olduğunda, öğrencinin öğrenme sürecinde yaşadığı başarısızlıklar karşısında ne derece toleranslı davranabildiğini ve başarısızlık ihtimali olsa bile güç işlemleri kolay işlemlere tercih etme eğilimini yansıtmaktadır. Yapılan farklı tanımlardan hareketle, akademik risk alma davranışı; öğrencinin 
emin olmadığı fikirleri paylaşmaktan, hata yapmaktan ve problemler karşısında yeni çözüm yolları denemekten çekinmemesi, sonucu net olarak kestirilemeyen durumları öğrenme için birer firsat olarak görmesi şeklinde ifade edilebilir.

Akademik risk alma düzeyi yüksek olan öğrenciler; $i$ ) öğrenme sürecinde karşılaştıkları zorluklara karşı direnç gösterir (Clifford, 1988), ii) başarısızlık ihtimali olsa bile sınıf içi etkinliklere katılma konusunda isteklidir (Strum, 1971), iii) öğrenme ortamında yüksek motivasyon (Clifford, 1988; House, 2002; İlhan, Çetin, Öner Sünkür ve Y1lmaz, 2013), öz yeterlilik (Clifford, Lan, Chou ve Qi, 1989; Taylor, 2010), zaman yönetimi (İlhan ve ark., 2013) ve problem çözme becerisine sahiptir (Tay, Özkan ve Akyürek Tay, 2009), iv) olumlu mükemmeliyetçi kişilik özellikleri gösterir (Öner Sünkür, İlhan, Kinay ve Kılınç, 2013), iv) öğrenme yönelimli olup (Ames, 1992), yeni bilgi ve beceriler kazanmak ve yeteneklerini geliştirmek için çalışırlar (Ames ve Archer, 1988; Braten ve Strømsø, 2004; Dupeyrat ve Mariné, 2005). Ayrıca akademik risk alma konusunda istekli olan öğrencilerin akademik beklentilere ilişkin yaşadıkları stres düşüktür (İlhan ve Çetin, 2013). Akademik risk alma düzeyi düşük olan öğrenciler ise; belirsizliğin doğurduğu bilgi yetersizliği nedeniyle zamanında karar verememekte ve buna bağlı olarak, öğrenmeye ilişkin fırsatları kaçırabilmektedir (Öner Sünkür, 2013). Diğer bir deyişle, öğrencinin akademik risk alma konusunda çekingen davranması, potansiyelini tam olarak ortaya koymasına engel olabilmektedir (Esen Kiran, 2005; Neihart, 2010). Bu bağlamda, akademik risk alma konusunda istekli olan öğrencilerin, 
isteksiz olan öğrencilere kıyasla başarıya ulaşma konusunda daha avantajlı olduğu söylenebilir (Donovan ve Bransford, 2005; Clifford, 1991; Clifford ve Chou, 1991; House, 2002; Korkmaz, 2009; Skaar, 2009).

Alanyazın incelendiğinde akademik risk alma ile ilgili çok sayıda çalışma yapıldığı görülmektedir. Bu çalışmaların büyük bir kısmında (Clifford, 1988; Clifford, 1991; Clifford ve Chou, 1991; İlhan ve ark., 2013; Korkmaz, 2002; Çiftçi, 2006; Öner Sünkür, 2013; Öner Sünkür ve ark., 2013; Özyılmaz Akamca, 2008; Yıldırım, Tay ve Ateş, 2007) akademik risk alma davranışı, herhangi bir alana yönelik değil; öğrenme-öğretme sürecine ilişkin genel bir özellik olarak ele alınmıştır. Ancak, akademik risk alma davranışı konu alanlarına göre farklılık göstermekte ve bir derste akademik risk alma konusunda istekli olan bir öğrenci, bir başka derste akademik risk alma konusunda çekingen davranabilmektedir. Meselâ; matematik dersinde akademik risk alma konusunda istekli olan bir öğrenci, sosyal bilgiler dersinde akademik risk almaktan kaçınabilmektedir. Bu durum, akademik risk alma davranışının, motivasyon, tutum, kaygı, öz yeterlilik vb. birçok duyuşsal özellikte olduğu gibi alan odaklı incelenmesi gerektiğini ortaya koymaktadır (İlhan ve Çetin, 2013). Bu gerekliliğin bir sonucu olarak, akademik risk alma davranışı Beghetto (2009) tarafından yapılan araştırmada fen odaklı, İlhan ve Çetin (2013) tarafından yapılan araştırmada ise matematik odaklı olarak incelenmiştir. Beghetto (2009) fen dersindeki her deneyin başarısızlık riski taşıdığını ve fen dersi ile ilgili olarak ortaya atılan herhangi bir hipotezin kabul edilme olasılığıyla 
birlikte, reddedilme ihtimalinin de bulunduğunu belirterek öğrencilerin akademik risk alma davranışlarını fen odaklı olarak incelemiştir. İlhan ve Çetin (2013) ise, fen bilimleri ve sosyal bilimler ile matematik arasında epistemolojik inanç, zekâya yönelik inanç ve öğrenme yaklaşımı gibi öğrenme sürecine ilişkin birçok özellik açısından görülen farkl1lıktan dolayı, matematik odaklı akademik risk alma davranışının diğer alanlara yönelik akademik risk alma davranışından ayrı olarak ele alınmasına gerektiğini savunmuş ve yaptıkları araştırmada, matematik odaklı akademik risk alma ölçeği geliştirmiştir. Sosyal bilgiler dersinin; fen bilimleri dersinin uygulamalı yapısı ile matematik dersinin soyut ve sembolik doğasından farklı bir içeriğe sahip olduğu (Steiner, 2007) dikkate alındığında, sosyal bilgiler odaklı akademik risk alma davranışının genel ve diğer alanlara yönelik akademik risk alma davranışından ayrı olarak incelenmesi ihtiyaç hâline gelmektedir. Bu kapsamda, araştırmada, akademik risk alma davranışının sosyal bilgiler odaklı olarak incelenmesine imkân tanıyacak bir ölçeğin geliştirilmesi amaçlanmaktadır.

\section{Yöntem}

\section{Araştırma Grubu}

Araştırma grubu, 2013-2014 Eğitim-Öğretim Y1lı Güz Dönemi'nde Diyarbakır ve İzmir illerinden 2'şer okul olmak üzere 4 farklı ortaokulda öğrenim gören 260’1 (\% 53.49) k1z ve 226’s1 (\% 46.50) erkek olmak üzere toplam 486 öğrenciden oluşmaktadır. Ancak, çok sayıda cevapsız maddenin bulunduğu, bir madde için birden fazla seçeneğin işaretlenmiş olduğu veya ölçme aracında yer alan olum- 
lu-olumsuz bütün maddelere aynı cevabın verilmiş olmasından dolayı maddeler okunmadan ölçme aracının doldurulduğu izlenimini uyandıran veriler, veri setinin dışında tutulmuştur. Bu nedenlerle, toplamda 12 (5 kız ve 7 erkek) öğrenciye ait veri, istatistiksel analizler gerçekleştirilmeden önce veri setinden çıkarılmıştır. Böylelikle çalışma grubunda, $255^{\prime}$ i (\% 53.80) k1z ve 219’u (\% 46.20) erkek olmak üzere toplam 474 öğrenciye ait veri kalmıştır. Bu öğrencilerin 163 'ü (\% 34.40) 6. sınıfa, $125^{\prime}$ i (\% 26.40) 7. sinifa ve 186 's1 (\% 39.20) 8. sinıfa devam etmektedir.

\section{İşlem}

SOARAÖ’nün geliştirilmesi sürecinde, Cronbach (1984), Crocker ve Algina (1986), Tezbaşaran (1997) ve DeVellis (2003) tarafından önerilen adımlar takip edilmiştir. Buna göre, ölçek geliştirme sürecinde izlenen basamaklar aşağıda özetlenmiştir.

\section{Ölçekten alınan puanlar ile ölçülecek özellik/özelliklerin be-}

\section{lirlenmesi}

SOARAÖ ile öğrencilerin sosyal bilgiler dersinde, akademik güçlüklerle mücadele etme konusundaki cesaretlerinin ve yaşadıkları başarısızlıkların ardından ne derece toleranslı davranabildiğinin ölçülmesi amaçlanmaktadır.

\section{Ölçülecek yapıyı temsil eden davranışların tanımlanması}

SOARAÖ geliştirilirken, Clifford (1991) tarafından geliştirilen genel akademik risk alma ölçeği ile İlhan ve Çetin (2013) tarafından geliştirilen matematik odaklı akademik risk alma ölçeğindeki GİTE, 
BSOE ve BSTE boyutları temele alınmıştır. GITE ile öğrencilerin sosyal bilgiler dersinde zor ödevleri kolay ödevlere tercih etme eğiliminin ölçülmesi amaçlanmaktadır. BSOE ile öğrencilerin sosyal bilgiler dersinde yaşadıkları başarısızlığın ardından olumsuz duygulara kapılma eğilimlerinin ölçülmesi hedeflenmektedir. BSTE boyutuyla ise, öğrencilerin sosyal bilgiler dersinde yaşadıkları başarısızlıkların ardından toparlanma ve aktif olma eğilimlerinin ölçülmesi amaçlanmaktadir.

\section{Ölçekte yer alacak maddelerin yazılması}

SOARAÖ'de yer alacak maddelerin yazımında, Clifford (1991) tarafından geliştirilen ve Korkmaz (2002) tarafından Türkçeye uyarlanan genel akademik risk alma ölçeği ile Beghetto (2009) tarafindan fen dersine yönelik olarak geliştirilen akademik risk alma ölçeği ve İlhan ve Çetin (2013) tarafindan geliştirilen matematik odaklı akademik risk alma ölçeğinden yararlanılmış; sosyal bilgiler öğretmenlerinin, sosyal bilgiler eğitimi ve eğitim bilimleri alanından uzmanların görüşlerine başvurulmuştur. Madde havuzu, ölçek geliştirme sürecinde temele alınan GITE, BSOE ve BSTE boyutlarından yola çıkılarak oluşturulmuştur. GITE boyutunu yansıtan 11 madde, BSOE boyutunu yansitan 6 madde ve BSTE boyutunu yansitan 6 madde yazılarak toplamda 23 maddeden oluşan bir madde havuzu elde edilmiştir. Ölçekte yer alan ifadeler için Kesinlikle Katılıyorum (5), Katılıyorum (4), Kararsızım (3), Katılmıyorum (2) ve Kesinlikle Katılmıyorum (1) şeklinde beşli likert tipi bir derecelendirme kullanılmıştır. 


\section{Taslak ölçme aracında yer alan maddeler için uzman görüşü} alınması ve ölçeğin yeniden gözden geçirilmesi

SOARAÖ’nün kapsam ve görünüş geçerliğini sağlamak için 1 ölçme değerlendirme uzmanı, 4 eğitim programları ve öğretim uzmanı ve 4 sosyal bilgiler eğitimi uzmanı olmak üzere toplam 9 uzmandan görüş alınmıştır. Bir konu ile ilgili kapsamın belirlenmesi bir yargılamayı gerektirdiğinden uzmanlar ile ölçme aracını geliştiren kişilerin ortak tanımlarının olması gereklidir (Tavşancıl, 2010). Özellikle, birden fazla alt ölçekten oluşan çok boyutlu ölçme araçlarında, ölçülmek istenen yapının farklı boyutlarını belirlemek amacıyla yazılan maddelerin, yer almaları beklenen boyut ile ilgili olup olmadığının uzmanlardan tarafından değerlendirilmesi gerekir (DeVellis, 2003). Bu gerekliliğe bağlı olarak, uzmanlardan, ölçeği, ölçek maddelerinin hazırlanması sürecinde araştırmacılar tarafından temele alınan GİTE, BSOE ve BSTE boyutları 1şı ğında değerlendirmeleri istenmiştir. Kapsam geçerliği ölçülürken, Lawshe (1975) tarafından önerilen yöntem kullanılmıştır. Bu yönteme göre, bir maddenin gerekliliği hakkında karar verirken, uzmanlar arasındaki uzlaşma miktarı esas alınmaktadır (Gözen, 2013). Uzmanlar SOARAÖ’de yer alan her bir maddeyi gerekli, faydalı fakat gereksiz ve gereksiz şeklinde üçlü derecelendirmeye sahip bir puanlama ölçeği ile değerlendirmiştir. Ölçekte yer alacak maddeler belirlenirken, 9 uzmandan en az 5 'inin gerekli şeklinde görüş bildirmiş olması ölçütü esas alınmıştır. Ölçme aracında yer alan 22 madde için gerekli şeklinde görüş bildiren uzman sayısının 5'den fazla olduğu belirlenmiştir. BSOE eğilimi boyutunu temsil etmek üzere yazılan "Sosyal Bilgiler dersinde harita kullanımı ile ilgili bir hata yaparsam 
karamsar hissederim" maddesi için 9 uzmandan 7'si gereksiz şeklinde görüş bildirmiştir. Dolayısıyla, uzmanların sosyal bilgiler dersindeki tek bir öğrenme alanına yönelik olarak nitelendirdiği bu madde ölçekten çıkarılmıştır. GITTE boyutunu yansıtan 11 madde, BSOE boyutunu yansitan 5 madde ve BSTE boyutunu yansitan 6 madde olmak üzere toplamda 22 maddeden oluşan bir ölçme aracı elde edilmiştir. Uzman görüşleri alındıktan sonra, ölçme aracının dil açısından anlaşılabilirliğini sağlamak amacıyla, 3 Türk dili uzmanının görüşüne başvurulmuştur. Uzmanların yazım kuralları ve noktalama işaretlerinin kullanımı ile ilgili görüşleri doğrultusunda, ölçek maddeleri gözden geçirilmiştir.

\section{Uygulama öncesinde küçük bir grup üzerinde ön uygulama}

\section{yapılması}

SOARAÖ'de yer alan maddelerin anlaşılırlığı ve ölçeğin uygulama süresi hakkında geri bildirim almak için, 8 ortaokul öğrencisi (4 k1z ve 4 erkek) üzerinde ön uygulama yapılmıştır. SOARAÖ’yü cevaplandıran öğrencilerle uygulamanın ardından görüşmeler gerçekleştirilmiştir. Görüşmelerde, öğrencilerin ölçekte yer alan maddelerin anlaş1lırlığına dâir fikirleri alınmıştır. Öğrencilere ayrıca, ölçeğin amacını, ölçekteki madde sayısını ve ölçeğin nasıl doldurulması gerektiğini belirtmek üzere ölçeğin başında sunulan yönerge hakkındaki düşünceleri sorulmuştur. Öğrencilerden alınan görüşler, ölçek için hazırlanan yönergede ve ölçek maddelerinde herhangi bir değişikliğe ihtiyaç duyulmadığını göstermiştir. Ölçeğin yaklaşık uygulama süresi, ön uygulamanın gerçekleştirildiği 8 kişilik grupta, ölçeği en kısa sürede 
dolduran öğrenci ile en uzun sürede dolduran öğrencinin cevaplama süresinin ortalaması olarak belirlenmiştir. Bu süreçlerden sonra ölçek geniş bir çalışma grubu üzerinde uygulamaya hazır hale gelmiştir.

\section{Ölçeğin, temsil özelliği yüksek geniş bir örnekleme uygu-} lanması ve ölçeğin psikometrik özelliklerini belirlemeye yönelik analizlerin gerçekleştirilmesi

Uygulamalar, ölçeğin psikometrik özelliklerini ortaya koymak için yeterli katılımcıdan (474 öğrenci) oluşan bir araştırma grubu üzerinde gerçekleştirilmiştir. Ölçek, sınıf ortamında öğrencilere uygulanmıştır. Uygulamaya başlamadan önce, öğrenciler araştırmanın amacı hakkında bilgilendirilmiştir. Öğrencilere, elde edilen verilerin yalnızca araştırmanın amacı için kullanılacağı, başka herhangi bir kurum ya da kişiyle paylaşılmayacağı belirtilmiştir. Yine uygulamadan önce, öğrencilere araştırmaya katılımın zorunlu olmadığ hatırlatılarak araştırma grubunun yalnızca gönüllü katılımcılardan oluşması sağlanmıştır. Öğrencilere, ölçeği nasıl doldurmaları gerektiği anlatılmış, maddeler hakkında doğru ya da yanlış cevapların bulunmadığı ifade edilmiş ve maddelerde verilen ifadelere dayalı olarak kendileri için uygun olan seçeneği işaretlemeleri istenmiştir. Öğrenciler, birbirlerini etkilememeleri konusunda uyarılmıştır. Ayrıca, ölçeği içtenlikle yanıtlamalarının geçerli ve güvenilir sonuçlar elde edilebilmesi için son derece önemli olduğu araştırmacı tarafından katılımcılara ifade edilmiştir. Veri toplama sürecinin ardından ölçeğin psikometrik özelliklerini belirlemeye yönelik olarak istatistiksel analizler gerçekleştirilmiştir. 


\section{Ölçeğin nasıl puanlanacağına ve nasıl yorumlanacağına iliş-}

\section{kin bir yönergenin hazırlanması}

SOARAÖ'nün alt boyutlarından ve ölçeğin genelinden alınabilecek puanların hangi aralıkta değişebileceği belirtilmiştir. Ayrıca, ölçeğin alt boyutlarından ve genelinden alınan yüksek ve düşük puanların nasıl yorumlanması gerektiği açıklanmıştır.

Geçerlik, güvenirlik ve madde analizine yönelik olarak gerçekleştirilen istatistiksel analizler

SOARAÖ araştırma grubuna uygulandıktan sonra, ölçeğin psikometrik özelliklerini ortaya koymak için istatistiksel analizler gerçekleştirilmiştir. İlk olarak ölçeğin yapı geçerliği incelenmiş, bu amaçla Açımlayıcı Faktör Analizi (AFA) ve Doğrulayıcı Faktör Analizi (DFA) uygulanmıştır. SOARAÖ'nün uyum geçerliği kapsamında, öğrencilerin ölçekten aldıkları puanlar ile sosyal bilgiler başarıları (bir önceki yıla ait karne notları) arasındaki korelasyon hesaplanmıştır. SOARAÖ'nün güvenirliği iç tutarlık yöntemiyle incelenmiştir. SOARAÖ'de yer alan maddelerin ayırt edicilik düzeylerini saptamak amacryla düzeltilmiş madde toplam korelasyonu hesaplanmış ve \% 27'lik alt-üst grup karşılaştırmalarına yer verilmiştir. Araştırmanın verileri SPSS 20.0 ve AMOS 20.0 paket programları kullanılarak analiz edilmiştir.

\section{Bulgular}

\section{Yapı Geçerliliği}

SOARAÖ'ye ilişkin kuramsal olarak temele alınan GITE, BSOE ve BSTE şeklindeki üç faktörlü yapının veriler tarafından doğrulanıp 
doğrulanmadığını test etmek için DFA uygulanmıştır. DFA sonucunda kuramsal olarak önerilen üç faktörlü yapı ile veri seti arasında anlamlı fark bulunduğu belirlenmiştir. Dolayısıyla, SOARAÖ’nün nasıl bir faktör yapısına sahip olduğunu ortaya koymak için AFA uygulanmıştır. AFA gerçekleştirilmeden önce verilerin faktör analizine uygun olup olmadığı konusunda karar vermek için KMO örneklem uygunluk katsayısı incelenmiş ve Bartlett Sphericity testleri gerçekleştirilmiştir. KMO 0 ile 1 arasında değişen değerler alabilmektedir. KMO değerinin .60'dan yüksek ve Bartlett testinin istatistiksel olarak anlamlı olması verilerin faktör analizi için uygun olduğunu göstermektedir (Büyüköztürk, 2010). Bu araştırmada, KMO değeri .838 bulunmuş ve Bartlett testinin istatistiksel olarak anlamlı olduğu $\left(\chi^{2}=1775.431\right.$, $\mathrm{sd}=231$ ) belirlenmiştir. $\mathrm{Bu}$ sonuca göre, verilerin faktör analizine uygun olduğu söylenebilir. Bu tespitin ardından AFA'da temel bileşenler yöntemi ve oblik döndürme sonucunda, toplam varyansın \% 32.21 'ini açıklayan iki faktörlü bir yapı elde edilmiştir. Clifford (1991) tarafından geliştirilen genel akademik risk alma ölçeği ile İlhan ve Çetin (2013) tarafından geliştirilen matematik odaklı akademik risk alma ölçeğinde, ölçek boyutlarının birbiri ile ilişkili olması, SOARAÖ’de de ölçek faktörleri arasında bir ilişki olacağını düşündürmüştür. Ölçek faktörlerinin birbirleriyle ilişkili olacağına yönelik bu öngörü nedeniyle AFA'da oblik döndürme tekniği kullanılmıştır. AFA sonucunda elde edilen bulgular Tablo 1'de sunulmuştur. 
Tablo 1. SOARAÖ AFA İlk Analiz Sonuçları

\begin{tabular}{l|c|c}
\hline Madde No & Faktör $\mathbf{~}$ & Faktör 2 \\
\hline SOARAÖ1 & $\mathbf{. 5 4 4}$ & -.034 \\
SOARAÖ2 & $\mathbf{. 5 7 3}$ & -.101 \\
SOARAÖ3 & -.095 & -.097 \\
SOARAÖ4 & $\mathbf{. 5 4 3}$ & -.062 \\
SOARAÖ5 & $\mathbf{. 4 2 9}$ & .093 \\
SOARAÖ6 & $\mathbf{. 5 5 5}$ & .198 \\
SOARAÖ7 & $\mathbf{. 5 7 7}$ & -.001 \\
SOARAÖ8 & $\mathbf{. 3 6 7}$ & -.007 \\
SOARAÖ9 & $\mathbf{. 4 2 8}$ & -.013 \\
SOARAÖ10 & $\mathbf{. 5 8 6}$ & -.070 \\
SOARAÖ11 & $\mathbf{. 3 6 4}$ & .247 \\
SOARAÖ17 & $\mathbf{. 5 8 5}$ & -.009 \\
SOARAÖ18 & $\mathbf{. 6 4 5}$ & -.054 \\
SOARAÖ19 & $\mathbf{. 6 0 0}$ & -.138 \\
SOARAÖ20 & $\mathbf{. 6 7 2}$ & .004 \\
SOARAÖ21 & $\mathbf{. 5 9 9}$ & -.083 \\
SOARAÖ22 & $\mathbf{. 5 3 2}$ & -.041 \\
SOARAÖ18 & -.115 & $\mathbf{. 6 9 2}$ \\
SOARAÖ19 & -.034 & $\mathbf{. 6 7 7}$ \\
SOARAÖ20 & -.003 & $\mathbf{. 6 9 9}$ \\
SOARAÖ21 & -.055 & $\mathbf{. 5 0 3}$ \\
SOARAÖ22 & -.067 & $\mathbf{. 6 7 8}$ \\
\hline & & \\
\hline
\end{tabular}

AFA'nın ilk sonuçlarına göre, GİTE ve BSTE boyutlarını temsil 
edecek şekilde yazılan maddeler birinci faktörde, BSOE boyutuna yönelik olarak yazılan maddeler ise ikinci faktörde yer almıştır. AFA sonucunda, madde 3 faktör yükü .30 'dan düşük olduğu için (Büyüköztürk, 2010; Costello ve Osborne, 2005; Martin ve Newell, 2004; Pallant, 2005; Schriesheim ve Eisenbach, 1995) ölçme aracindan çıkarılmıştır. Daha sonra, AFA tekrarlanmış ve toplam varyansın \% 33.86'sını açıklayan iki faktörlü bir yapı elde edilmiştir. Faktörlerde toplanan maddelerin içerikleri dikkate alındığında, birinci faktörde GITE ve BSTE’yi yansıtan maddelerin yer aldığı belirlenmiştir. İkinci faktörde ise, BSOE'ye yönelik maddelerin bulunduğu belirlenmiştir. GITE ile BSTE eğilimi boyutları öğrencilerin akademik risk alma konusundaki istekliliklerini yansıtırken; BSOE boyutu, öğrencilerin akademik risk alma konusundaki isteksizliklerine işaret etmektedir. $\mathrm{Bu}$ noktadan hareketle, GITE ile BSTE'ye yönelik maddelerin yer aldığı birinci faktör Akademik Risk Almaya Yaklaşma (ARAY); BSOE'i yansıtan maddeler ise, Akademik Risk Almaktan Kaçınma (ARAK) olarak adlandırılmıştır. ARAY alt ölçeği 16 maddeden oluşmakta ve toplam varyansın \% 23.11'ini açıklamaktadır. Bu alt ölçekte yer alan maddelerin faktör yükleri .35 ile .67 arasında sıralanmaktadır. ARAK alt ölçeği toplam varyansın \% 10.76'sını açıklamaktadır. Bu alt ölçekte yer alan maddelerin faktör yükleri .51 ile .70 arasında değişmektedir. SOARAÖ’nün açıkladığı varyans oranı ile faktör yüklerine ilişkin bulgular Tablo 2'de gösterilmiştir.

Tablo 2. SOARAÖ Çıkarılan Maddenin Ardından Tekrarlanan AFA Sonuçları 


\begin{tabular}{|c|c|c|c|}
\hline Faktör & $\begin{array}{l}\text { Madde } \\
\text { No }\end{array}$ & Maddeler & $\begin{array}{l}\text { Faktör } \\
\text { Yükü }\end{array}$ \\
\hline \multirow{14}{*}{ ARAY } & M1 & $\begin{array}{l}\text { Sosyal bilgiler dersinin anlaşılması güç olan } \\
\text { konularını tartışmayı severim. }\end{array}$ & .556 \\
\hline & M2 & $\begin{array}{l}\text { Hata yapma ihtimalim olsa bile sosyal bir problemi } \\
\text { tartışırken farklı bakış açıları belirtmekten } \\
\text { kaçınmam. }\end{array}$ & .589 \\
\hline & M4 & $\begin{array}{l}\text { Sosyal bilgiler dersi ödevlerini seçme şansim } \\
\text { olduğunda zor olan ödevleri kolay olanlara tercih } \\
\text { ederim. }\end{array}$ & .547 \\
\hline & M5 & $\begin{array}{l}\text { Ezberlenerek doğru yanıtlanabilecek sorular yerine, } \\
\text { tartışmaya açı konular üzerinde fikirlerimi } \\
\text { söylemek daha keyiflidir. }\end{array}$ & .410 \\
\hline & M6 & $\begin{array}{l}\text { Bazı yanlışlar yapsam bile zor olan sosyal bilgiler } \\
\text { dersi ödevleriyle uğraşmayı severim. }\end{array}$ & .560 \\
\hline & M7 & $\begin{array}{l}\text { Farklı düşünmeyi gerektiren sosyal bilgiler dersi } \\
\text { konularına çalışmak eğlencelidir. }\end{array}$ & .577 \\
\hline & M8 & $\begin{array}{l}\text { Kolay fakat sıkıcı bir sosyal bilgiler dersi ödevinde } \\
\text { mükemmel bir not almaktansa zor bir ödevde hata } \\
\text { yapmayı tercih ederim. }\end{array}$ & .354 \\
\hline & M9 & $\begin{array}{l}\text { Sosyal Bilgiler dersinde doğruluğundan emin } \\
\text { olmadığım fikirleri paylaşmaktan çekinmem. } \\
\text { İyi olmadığım sosyal bilgiler dersi konularıyla ilgili }\end{array}$ & .434 \\
\hline & M10 & $\begin{array}{l}\text { bir soru ile karşılaştığımda bile cevaplamak için } \\
\text { uğraşırım. }\end{array}$ & .597 \\
\hline & M11 & $\begin{array}{l}\text { Sosyal Bilgiler dersi sınavında tercihli soru } \\
\text { sorulursa, düşük puan alma ihtimaline karşı yine de } \\
\text { zor olan soruları tercih ederim. }\end{array}$ & .367 \\
\hline & M17 & $\begin{array}{l}\text { Sosyal Bilgiler dersinde yaptığım hataları öğrenme } \\
\text { için bir firsat olarak görürüm. }\end{array}$ & .594 \\
\hline & M18 & $\begin{array}{l}\text { Sosyal Bilgiler dersinde düşük bir not alırsam } \\
\text { zihnimi toplayıp daha sıkı çalışırım. }\end{array}$ & .634 \\
\hline & M19 & $\begin{array}{l}\text { Sosyal Bilgiler dersinde düşük bir not alırsam, hata } \\
\text { ve eksiklerimi açıklaması için öğretmenime veya } \\
\text { arkadaşlarıma sorarım. }\end{array}$ & .613 \\
\hline & M20 & $\begin{array}{l}\text { Sosyal Bilgiler dersinde zorlandığım bir konuyu } \\
\text { anlamak için tekrar tekrar çalışırım. }\end{array}$ & .665 \\
\hline
\end{tabular}




\begin{tabular}{|c|c|c|c|}
\hline & M21 & $\begin{array}{l}\text { Sosyal Bilgiler dersinde düşük bir not alsam da } \\
\text { çalışarak notumu yükseltebilirim. } \\
\text { Sosyal Bilgiler dersinde bildiğim ifadelerden yola } \\
\text { çıarak konu ile ilgili genellemeler yapmaktan } \\
\text { çekinmem. }\end{array}$ & .601 \\
\hline & & Açıkladığı Varyans \% & 23.107 \\
\hline & M12 & $\begin{array}{l}\text { Sosyal Bilgiler dersinde bir konu ile ilgili yanlış } \\
\text { cevap verdiğim zaman cesaretim çok kırılır. }\end{array}$ & .700 \\
\hline & M13 & $\begin{array}{l}\text { Sosyal Bilgiler dersi ödevlerinde yanlış yapmaktan } \\
\text { endişe duyarım. }\end{array}$ & .674 \\
\hline ARAK & M14 & $\begin{array}{l}\text { Sosyal Bilgiler dersi ödevinde başarısız olduğum } \\
\text { zaman hiçbir şey bana keyif vermez. }\end{array}$ & .701 \\
\hline & M15 & $\begin{array}{l}\text { Sosyal bilgiler dersinde kötü bir not aldığım zaman } \\
\text { bunu kimsenin duymasını istemem. }\end{array}$ & .513 \\
\hline & M16 & $\begin{array}{l}\text { Bir Sosyal Bilgiler dersi ödevini yaparken başarısız } \\
\text { olursam hemen vazgeçerim. }\end{array}$ & .679 \\
\hline & & Açıkladığı Varyans \% & 10.756 \\
\hline & & AÇIKLANAN TOPLAM VARYANS \% & 33.863 \\
\hline
\end{tabular}

AFA sonucunda elde edilen 21 madde ve iki faktörden oluşan yapının yeterli uyum indeksleri verip vermediğini belirlemek ve SOARAÖ’nün yapı geçerliğine ilişkin ek kanıt elde etmek için DFA uygulanmıştır. DFA'da sınanan modelin yeterliliğini ortaya koymak üzere pek çok uyum indeksi kullanılmaktadır. Bu çalışmada, yapılan DFA için Ki-Kare uyum testi (Chi-Square Goodness), iyilik uyum indeksi (Goodness of Fit Index, GFI), düzeltilmiş iyilik uyum indeksi (Adjustment Goodness of Fit Index, AGFI), karşılaştırmalı uyum indeksi (Comparative Fit Index, CFI), normlaştırılmış uyum indeksi (Normed Fit Index, NFI), Tucker Lewis indeksi (TLI), fazlalık uyum indeksi (Incremental Fit Index, IFI), tahmin hatalarının ortalamasının karekökü (Root Mean Square Error of Approximation, RMSEA), 
standartlaştırılmış hata kareleri ortalamasının karekökü (Standardized Root Mean Square Residual, SRMR), sıkı normlaştırılmış uyum indeksi (Parsimony Normed Fit Index, PNFI) ve sıkı iyilik uyum indeksi (Parsimony Goodness of Fit Index, PGFI) incelenmiştir. Uyum indekslerine ilişkin dikkate alınması gereken ölçütler tartışmalı bir konudur (Weston ve Gore, 2006). Bununla birlikte genel olarak; GFI, CFI, NFI, TLI ve IFI indeksleri için .90 değeri kabul edilebilir uyuma ve .95 değeri mükemmel uyuma işaret etmektedir (Bentler, 1980; Bentler ve Bonett, 1980; Marsh, Hau, Artelt, Baumert ve Peschar, 2006). AGFI için .85 değeri kabul edilebilir uyumu ve .90 değeri mükemmel uyumu ifade etmektedir (Schermelleh-Engel ve Moosbrugger, 2003). RMSEA için .08 değeri kabul edilebilir uyum ve .05 değeri mükemmel uyum ölçütü olarak alınmaktadır (Brown ve Cudeck, 1993; Byrne ve Campbell, 1999). SRMR için ise .05 değeri mükemmel uyuma ve .10 değeri kabul edilebilir uyuma işaret etmektedir (Hu ve Bentler, 1999; Kline, 2011). PNFI ve PGFI uyum indekslerinin .50'nin üzerinde olması kabul edilebilir uyumu (Meyers, Gamst ve Guarino, 2006) .95 ve üzerinde olması ise, mükemmel uyumu ifade etmektedir (Meydan ve Şeşen, 2011). Yapılan DFA'da, elde edilen modelin uyum indeksleri incelenmiş ve minimum $\chi^{2}$ değerinin $\left(\chi^{2}=458.82, N=474, p=.00\right)$ anlamlı olduğu görülmüştür. Uyum indeksi değerleri ise, $\mathrm{GFI}=.91, \mathrm{AGFI}=.89, \mathrm{CFI}=.93, \mathrm{NFI}=.89, \mathrm{TLI}=92$, $\mathrm{IFI}=.93, \mathrm{RMSEA}=.058, \mathrm{SRMR}=.054, \mathrm{PNFI}=.79$ ve $\mathrm{PGFI}=.74$ olarak bulunmuştur. Sınanan modelin yeterliğini ortaya koymak amacıyla incelenen uyum indekslerine ilişkin kabul edilebilir ve mükemmel uyum değerleri ile DFA'dan elde edilen uyum indeksi değerleri ve bu 
doğrultuda ortaya çıkan sonuçlar Tablo 3 'te gösterilmiştir.

Tablo 3. Araştırmada İncelenen Uyum İndekslerine İlişkin Mükemmel ve Kabul Edilebilir Uyum Değerleri ile DFA'dan Elde Edilen Uyum İndeksi Değerleri

\begin{tabular}{|c|c|c|c|c|}
\hline 冚 & 蒠 & 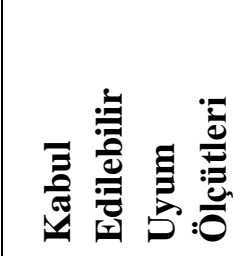 & 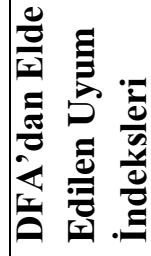 & 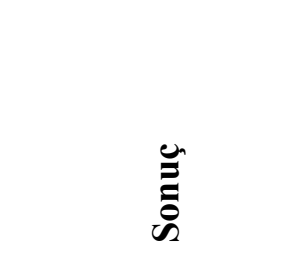 \\
\hline$\chi^{2} / \mathrm{sd}$ & $0 \leq \chi^{2} / \mathrm{sd} \leq 2$ & $2 \leq \chi^{2} / \mathrm{sd} \leq 3$ & 2.44 & Kabul Edilebilir Uyum \\
\hline GFI & $.95 \leq \mathrm{GFI} \leq 1.00$ & $.90 \leq \mathrm{GFI} \leq 95$ & .91 & Kabul Edilebilir Uyum \\
\hline AGFI & $.90 \leq \mathrm{AGFI} \leq 1.00$ & $.85 \leq \mathrm{AGFI} \leq .90$ & .89 & Kabul Edilebilir Uyum \\
\hline CFI & $.95 \leq \mathrm{CFI} \leq 1.00$ & $.90 \leq \mathrm{CFI} \leq .95$ & .93 & Kabul Edilebilir Uyum \\
\hline NFI & $.95 \leq \mathrm{NFI} \leq 1.00$ & $.90 \leq \mathrm{NFI} \leq .95$ & .89 & Kabul Edilebilir Uyum \\
\hline TLI & $.95 \leq \mathrm{TLI} \leq 1.00$ & $.90 \leq \mathrm{TLI} \leq .95$ & .92 & Kabul Edilebilir Uyum \\
\hline IFI & $.95 \leq \mathrm{IFI} \leq 1.00$ & $.90 \leq \mathrm{IFI} \leq .95$ & .93 & Kabul Edilebilir Uyum \\
\hline RMSEA & $.0 \leq \mathrm{RMSEA} \leq .05$ & $.05 \leq \mathrm{RMSEA} \leq .08$ & .058 & Kabul Edilebilir Uyum \\
\hline SRMR & $.00 \leq \mathrm{SRMR} \leq .05$ & $.05 \leq \mathrm{SRMR} \leq .10$ & .054 & Kabul Edilebilir Uyum \\
\hline PNFI & $.95 \leq \mathrm{PNFI} \leq 1.00$ & $.50 \leq \mathrm{PNFI} \leq .95$ & .79 & Kabul Edilebilir Uyum \\
\hline PGFI & $.95 \leq \mathrm{PGFI} \leq 1.00$ & $.50 \leq \mathrm{PGFI} \leq .95$ & .74 & Kabul Edilebilir Uyum \\
\hline
\end{tabular}

Tablo 3'teki uyum indekslerine ilişkin mükemmel ve kabul edilebilir uyum ölçütleri, SOARAÖ’ye ilişkin iki faktörlü modelin uyumlu olduğunu ortaya koymaktadır. İki boyutlu modele ilişkin faktör yükleri Şekil 1'de görülmektedir. Şekil 1'de görülebileceği gibi, faktör yükleri ARAY alt boyutu için .25 ile .62 arasında ve ARAK alt boyutu için ise .40 ile .62 arasında değişmektedir. 

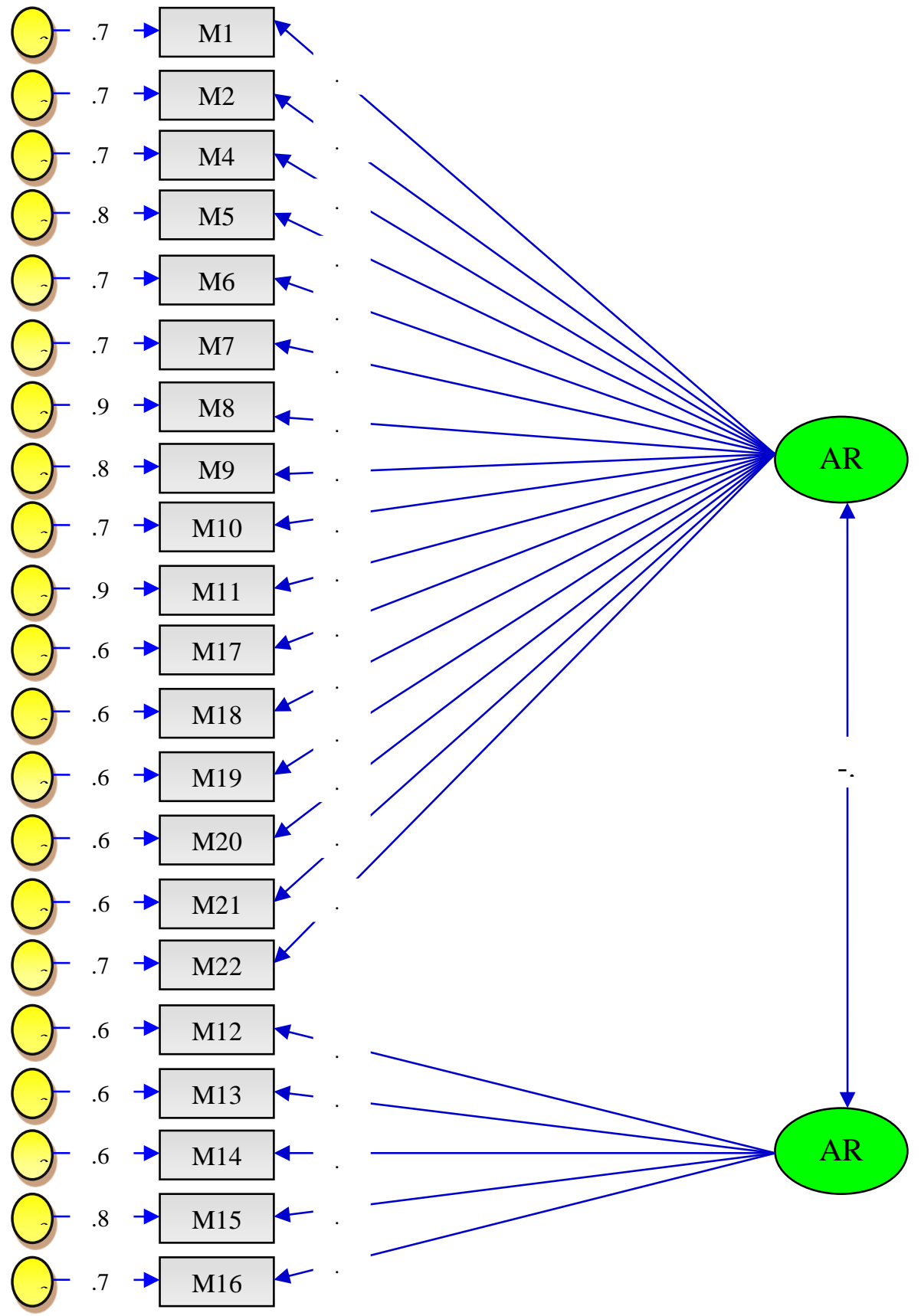

Şekil 1. SOARAÖ Path Diyagramı ve Faktör Yükleri 


\section{Uyum Geçerliği}

Akademik risk alma davranışına ilişkin literatür incelendiğginde, akademik risk alma ile başarı arasında pozitif ilişki olduğu görülmektedir (Özyılmaz Akamca, 2008). Buna göre, SOARAÖ’nün uyum geçerliği kapsamında, öğrencilerin ölçekten aldıkları puanlar ile Sosyal Bilgiler dersi başarıları arasındaki korelasyon hesaplanmıştır. Öğrencilerin bir önceki yıla ait Sosyal Bilgiler karne notları sosyal bilgiler başarı puanı olarak alınmıştır. Sosyal Bilgiler başarısı ile Sosyal Bilgiler odaklı akademik risk alma davranışı arasında pozitif bir ilişkinin bulunduğu hipotezi test edilmiştir. Korelasyon analizi sonucunda, Sosyal Bilgiler başarısı ile Sosyal Bilgiler odaklı akademik risk alma arasında pozitif yönde ve zayıf ancak istatistiksel olarak anlamlı bir ilişki saptanmıştır [ $n=474, r=.21, p<.001]$. Bu bulgular, SOARAÖ’nün uyum geçerliğinin sağlandığına yönelik bir kanıt olarak değerlendirilmiştir.

\section{Güvenirlik}

SOARAÖ’nün güvenirliği, iç tutarlılık yöntemi ile hesaplanmıştır. Araştırmada 474 öğrenciden elde edilen veriler üzerinden hesaplanan iç tutarlılık katsayıları, ARAY alt ölçeği için .81, ARAK alt ölçeği için .68 ve ölçeğin geneli için .78 olarak bulunmuştur. Genel olarak güvenirlik katsayısı .70 ve üzerinde olan ölçeklerin güvenilir olduğu kabul edilmektedir (Domino ve Domino, 2006; Fraenkel, Wallend ve Hyun, 2012; Leech, Barlett ve Morgan, 2005; Pallant, 2005; Tezbaşaran, 1997; Urbina, 2004). Bununla birlikte, madde sayısı az olan (10 ya da daha az) ölçekler için, güvenirlik 
katsayısının .60 ve üzerinde olması ölçeğin güvenirliği için yeterli görülmektedir (Sipahi, Yurtkoru ve Çinko, 2010; Şeker ve Gençdoğan, 2006). Güvenirlik katsayısına ilişkin bu ölçütlere göre, SOARAÖ için hesaplanan güvenirlik katsayılarının kabul edilebilir sınırlar içerisinde yer aldı̆̆ söylenebilir.

\section{Madde Analizi}

SOARAÖ'de yer alan maddelerin ayırt edicilik düzeylerini belirlemek ve toplam puanı yordama gücünü saptamak amaciyla düzeltilmiş madde toplam korelasyonu hesaplanmış ve $\% 27$ 'lik alt-üst grup karşılaştırmalarına yer verilmiştir. Düzeltilmiş madde toplam korelasyonun hesaplanmasında Pearson Momentler Çarpımı Korelasyonu kullanılmıştır. \% 27'lik alt üst grup karşılaştırmalarında ise ilişkisiz örneklem $t$ testinden yararlanılmıştır. Madde analizi sonucunda elde edilen bulgular Tablo 4'te sunulmuştur. Tablo 4'teki bulgular incelendiğinde, \% 27'lik alt ve üst grupların madde puanlarındaki farklara ilişkin $t$ değerlerinin ARAY alt ölçeği için 8.02 ile 13.37 arasında $(s d=250, p<.001)$ ve ARAK alt ölçeği için 13.52 ile 24.17 arasında $(s d=267, p<.001)$ değiştiği görülmektedir. Tablo 4'e göre ayrıca, madde toplam korelasyonuna ilişkin sonuçlar, ARAY alt ölçeği için .24 ile .55 arasında ve ARAK alt ölçeği için .33 ile .48 arasında sıralanmaktadır. Madde toplam korelasyonu yorumlanırken değeri .30 ve üzerinde olan maddeler, ölçülecek özelliği ayırt etme açısından yeterli kabul edilmektedir (Büyüköztürk, 2010; Erkuş, 2012; Field, 2009). ARAY alt ölçeğinde yer alan 8. madde dişındaki maddelerin tamamı bu ölçütü sağlar niteliktedir. Bununla birlikte, \% 27'lik alt-üst 
grup karşılaştırmaları sonucu elde edilen $t$ değerlerinin düzeltilmiş madde toplam korelasyonu .30'un altında olan bu madde için de anlamlı olduğu görülmektedir. Alt ve üst grup arasındaki farklara ilişkin $t$ değerlerinin anlamlı olması maddenin ayırt ediciliği için bir kanıt olarak değerlendirilmektedir (Erkuş, 2012). Bu bulgulardan hareketle, ölçekte yer alan maddelerin tamamının ayırt edici olduğu söylenebilir.

Tablo 4. SOARAÖ Madde Analizi Sonuçları

\begin{tabular}{|c|c|c|c|c|c|c|c|}
\hline \multirow[b]{2}{*}{ Alt Boyut } & \multirow[b]{2}{*}{$\begin{array}{l}\text { Madde } \\
\text { No }\end{array}$} & \multicolumn{3}{|c|}{ Madde Çıkarıldığında } & \multirow{2}{*}{$\begin{array}{l}\text { Düzeltilmiş } \\
\text { Madde } \\
\text { Toplam } \\
\text { Korelasyonu }\end{array}$} & \multirow[b]{2}{*}{$t$} & \\
\hline & & $\begin{array}{l}\text { Ölçek } \\
\text { Ortalaması }\end{array}$ & $\begin{array}{l}\text { Ölçek } \\
\text { Varyansı }\end{array}$ & $\begin{array}{l}\text { Ölçek } \\
\text { Alfası }\end{array}$ & & & \\
\hline \multirow{13}{*}{ Cronbach } & M1 & 59.56 & 74.355 & .801 & .464 & $11.18^{* *}$ & \multirow{13}{*}{$\begin{array}{l}s d=250 \\
\quad p * .001\end{array}$} \\
\hline & M2 & 59.49 & 75.192 & .800 & .475 & $11.94^{* *}$ & \\
\hline & M4 & 59.54 & 75.303 & .802 & .446 & $12.22^{* *}$ & \\
\hline & M5 & 59.42 & 76.685 & .811 & .311 & $8.02^{* *}$ & \\
\hline & M6 & 59.66 & 72.131 & .800 & .476 & $12.26^{* *}$ & \\
\hline & M7 & 59.41 & 74.247 & .799 & .489 & $11.74^{* *}$ & \\
\hline & M8 & 61.28 & 76.481 & .819 & .242 & $8.27^{* *}$ & \\
\hline & M9 & 59.79 & 75.010 & .810 & .341 & $11.30^{* *}$ & \\
\hline & M10 & 59.38 & 74.638 & .800 & .484 & $11.73^{* *}$ & \\
\hline & M11 & 60.57 & 74.653 & .815 & .308 & $9.85^{* * *}$ & \\
\hline & M17 & 59.33 & 75.429 & .801 & .463 & $12.66^{* *}$ & \\
\hline & M18 & 59.10 & 76.186 & .800 & .519 & $13.31^{* *}$ & \\
\hline & M19 & 59.28 & 75.480 & .801 & .471 & $10.96^{* *}$ & \\
\hline
\end{tabular}




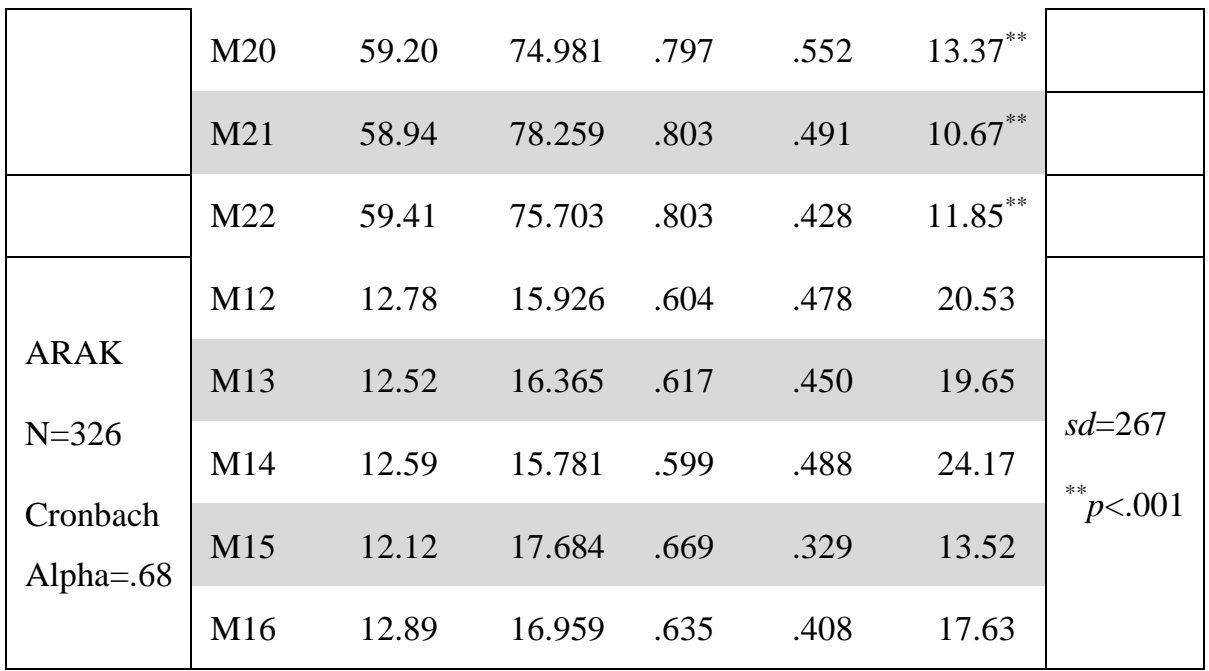

SOARAÖ’nün Puanlarının Değerlendirilmesi. SOARAÖ’de 21 madde bulunmaktadır. Ölçekte 5'li Likert tipi bir derecelendirme kullanılmıştır. Ölçek, ARAY ve ARAK olmak üzere iki boyutlu bir yapıya sahiptir. ARAY boyutunda, öğrencilerin güç işlemleri tercih etme eğilimi ile başarısızlık sonrası toparlanma eğilimini destekleyen 16 madde bulunmaktadır. ARAK boyunda ise, öğrencilerin başarısızlık sonrası olumsuzluk eğilimini yansıtan 5 madde yer almaktadır. ARAY alt ölçeğinde yer alan ifadeler akademik risk almayı desteklediğinden bu boyuttaki maddeler düz; ARAK alt ölçeğinde bulunan maddeler akademik risk almayı desteklemediğinden bu boyuttaki maddeler ters kodlanarak öğrencilerin Sosyal Bilgiler dersinde akademik risk alma düzeylerine ilişkin toplam bir puan elde edilebilmektedir. Öğrencilerin ölçekten aldıkları puanlar yükseldikçe, Sosyal Bilgiler dersinde akademik risk alma düzeyleri de artmaktadır. 


\section{Tartışma ve Sonuç}

$\mathrm{Bu}$ araştırmada, öğrencilerin Sosyal Bilgiler odaklı akademik risk alma düzeylerini geçerli ve güvenilir olarak ölçmeye imkân tanıyacak bir ölçme aracının geliştirilmesi amaçlanmıştır. SOARAÖ geliştirilirken, Clifford (1991) tarafından geliştirilen genel akademik risk alma ölçeği ile İlhan ve Çetin (2013) tarafından geliştirilen matematik odaklı akademik risk alma ölçeğindeki GİTE, BSOE ve BSTE boyutları dikkate alınmıştır. GİTE'yi yansıtan 11 madde, BSOE'yi yansıtan 6 madde ve BSTE'yi yansıtan 6 madde olmak üzere toplam 23 maddeden oluşan bir madde havuzu oluşturulmuştur. Ölçeğin kapsam ve görünüş geçerliğini sağlamak için uzman görüşü alınmıştır. Uzman görüşleri doğrultusunda, BSOE boyutundan 1 madde çıkarılmıştır. Böylelikle 22 maddelik taslak bir ölçme aracı elde edilmiştir. 22 madde "Kesinlikle Katılıyorum (5)" ile “Kesinlikle Katılmıyorum (1)" şeklinde beşli likert tipi bir derecelendirme ile araştırma grubundaki öğrencilere uygulanmiştır.

SOARAÖ’ye ilişkin kuramsal olarak temele alınan GİTE, BSOE ve BSTE şeklindeki üç faktörlü yapının veriler ile uyumlu olup olmadığını ortaya koymak için DFA uygulanmıştır. DFA sonucunda, verilerin kuramsal olarak test edilen üç faktörlü yapıyı doğrulamadığı belirlenmiştir. Dolayısıyla, SOARAÖ’nün nasıl bir faktör yapısına sahip olduğunu ortaya koymak için AFA uygulanmıştır. AFA sonucunda bir madde ölçekten çıkarılmış, kalan 21 maddenin toplam varyansın \%33.86'sını açıklayan iki faktörlü bir yapıya sahip olduğu belirlenmiştir. Faktörlerde toplanan maddelerin içerikleri dikkate alınarak; 
GİTE ve BSTE'yi yansıtan maddelerin toplandığı birinci faktör ARAY, BSOE'yi yansıtan maddelerin toplandığı ikinci faktör ARAK olarak adlandırılmıştır. AFA'dan elde edilen iki faktörlü yapının yeterli uyum indeksi verip vermediğini belirlemek ve SOARAÖ’nün yapı geçerliğine ilişkin ek kanıt elde etmek için DFA uygulanmıştır. DFA'dan elde edilen bulgular, SOARAÖ’ye ilişkin iki faktörlü yapıya ait uyum indekslerinin yeterli olduğunu göstermiştir. AFA'da açıklanan varyans oranı için \% 30 ve üzerindeki değerlerin ölçüt olarak alındığı (Bayram, 2009; Büyüköztürk, 2010), ölçekte yer alan maddelere ait faktör yüklerinin .30 alt sınırının (Büyüköztürk, 2010; Costello ve Osborne, 2005; Pallant, 2005; Schriesheim ve Eisenbach, 1995) üzerinde olduğu ve DFA'dan elde edilen uyum indekslerinin kabul edilebilir sınırlar içerisinde yer aldığı düşünüldüğünde, SOARAÖ’nün yapı geçerliğinin sağlandığı söylenebilir.

SOARAÖ’nün uyum geçerliği için, öğrencilerin ölçekten aldıkları puanlar ile Sosyal Bilgiler başarıları arasındaki korelasyon hesaplanmıştır. Öğrencilerin bir önceki döneme ait Sosyal Bilgiler karne notları, Sosyal Bilgiler başarı puanı olarak alınmıştır. Korelasyon analizinden elde edilen bulgular, öğrencilerin Sosyal Bilgiler odaklı akademik risk alma düzeyleri ile Sosyal Bilgiler başarıları arasındaki ilişkinin akademik risk alma davranışına ilişkin literatür ile örtüştüğünü göstermiştir.

SOARAÖ’nün güvenirliği, iç tutarlık yöntemiyle incelenmiştir. Hesaplanan iç tutarlık katsayıları ARAY alt ölçeği için .81, ARAK alt ölçeği için .68 ve ölçeğin geneli için .78 şeklindedir. Güvenirlik kat- 
sayısı 70 ve üzerinde olan ölçeklerin güvenilir kabul edildiği (Anastasi, 1982; Muijs, 2004; Nunnaly ve Bernstein, 1994; Sipahi, Yurtkoru, ve Çinko, 2010; Stangor, 2010) göz önüne alındığında, hesaplanan iç tutarlık katsayıları ölçeğin güvenirliğine yönelik bir kanıt olarak değerlendirilebilir.

SOARAÖ'de yer alan maddelerin toplam puanı yordama gücünü belirlemek ve ayırt edicilik düzeylerini saptamak amacıyla madde analizi yapılmıştır. Madde analizi kapsamında, düzeltilmiş madde toplam korelasyonu incelenmiş ve \% 27'lik alt-üst grup karşılaştırmalarına yer verilmiştir. Analiz sonucunda, düzeltilmiş madde toplam korelasyonlarının ARAY alt ölçeği için .24 ile .55 arasında ve ARAK alt ölçeği için .33 ile .48 arasında sıralandığı ve \% 27’lik alt ve üst grup arasındaki farklara ilişkin $t$ değerlerin ölçekte yer alan bütün maddeler için anlamlı olduğu belirlenmiştir. Bu bulgular, SOARAÖ’de yer alan maddelerin tamamının ayırt edici olduğuna işaret etmektedir.

Araştırmada, SOARAÖ’nün psikometrik özelliklerini incelemek amacıyla gerçekleştirilen istatistiksel analizlerden elde edilen bulgular, ölçeğin öğrencilerin sosyal bilgiler dersinde akademik risk alma davranışlarını belirlemede geçerli ve güvenilir bir araç olarak kullanılabileceğini ortaya koymaktadır. Sonuç olarak, Türk kültürüne öğrencilerin sosyal bilgiler odaklı akademik risk alma davranışlarını ölçmek amacıyla kullanılabilecek bir ölçek kazandırmayı amaçlayan bu çalışma ile öğrencilerin Sosyal Bilgiler dersinde başarısızlıklar karşısında ne derece toleranslı davrandığını ve güç işlemleri tercih etme eğilimlerini ölçmede kullanılabilecek yeterli psikometrik özelliklere sahip bir 
ölçme aracına ulaşıldığı söylenebilir.

\section{Araştırmanın Sınırlııkları ve İleri Araştırmalara Yönelik Öneriler}

Alanyazın incelendiğinde, hem Türkçe literatürde hem de uluslararası literatürde genel akademik risk alma ölçeğinin bulunduğu görülmektedir. Alan odaklı akademik risk alma ölçeklerine bakıldığında ise; uluslararası literatürde fen odaklı, Türkçe literatürde matematik odaklı akademik risk alma ölçeklerinin bulunduğu belirlenmiştir. Ancak, öğrencilerin Sosyal Bilgiler odaklı akademik risk alma davranışlarını ölçmek amacıyla kullanılabilecek bir ölçeğe literatürde rastlanmamıştır. SOARAÖ’nün geliştirilmesinin amaçlandığı bu çalışmanın literatürdeki bu boşluğu dolduracak olması yönüyle önemli olduğu düşünülmektedir. Bununla birlikte, bu ölçek geliştirme çalışmasının yalnızca ortaokul öğrencilerinden oluşan bir araştırma grubu üzerinde yürütülmüş olması, SOARAÖ’nün sadece ortaokul öğrencilerinde geçerliği kanıtlanmış bir ölçme aracı olduğu anlamına gelebilir. $\mathrm{Bu}$ durum SOARAÖ'nün faktör yapısının farklı eğitim kademelerinden örneklemler üzerinde de sınanmasını gerektirmektedir. Ayrıca, bu araştırmada SOARAÖ’nün yapı geçerliğine yönelik çalışmalar AFA ve DFA ile sınırlı tutulmuş olup SOARAÖ’nün kullanılacağı ileri araştırmalarda, ölçeğin yapı geçerliğinin yakınsak ve ıraksak geçerlik çalışmalarıyla da test edilmesi önerilebilir.

Bu araştırmada, SOARAÖ’nün ölçüt bağıntılı geçerlik çalışması kapsamında, öğrencilerin SOARAÖ'den aldıkları puanlar ile Sosyal Bilgiler başarıları arasındaki ilişki incelenmiştir. Akademik risk alma ile ilgili literatür incelendiğinde, akademik risk alma davranışının s1- 
nava hazırlanma ve sınav kaygısı yönetimi ile zaman yönetimi becerisi, motivasyon (İlhan ve ark., 2013), olumlu ve olumsuz mükemmeliyetçilik (Öner Sünkür ve ark., 2013), problem çözme becerisi (Tay, Özkan ve Akyürek Tay, 2009) ve akademik beklentilere ilişkin stres (İlhan ve Çetin, 2013) gibi birçok değişken ile ilişkili olduğu görülmektedir. Bu noktadan hareketle, sosyal bilgiler odaklı akademik risk alma davranıŞının sıralanan değişkenler ile nasıl bir ilişki içerisinde olduğunu belirlemeye yönelik ileri araştırmaların yapılması önerilebilir. SOARAÖ’nün kullanılacağı ileri araştırmaların yapılması ölçeğin ölçme gücüne katkı sağlayacak olması açısından oldukça önemlidir.

Bu araştırmada, SOARAÖ’nün güvenirliği iç tutarlık, yöntemiyle hesaplanmıştır. Ancak çalışmada ölçeğin test tekrar test güvenirliğini belirlemeye yönelik herhangi bir uygulama gerçekleştirilmemiştir. Ölçekten alınan puanların zamana karşı değişmezliğinin ortaya konulabilmesi için ileri araştırmalarda SOARAÖ'nün test tekrar test güvenirliğinin hesaplanması gerekmektedir. Son olarak, bu araştırmada genel öğrenme yaklaşımları ölçeğinden farklı olarak, alan odaklı öğrenme yaklaşımları ölçeğinin geliştirilmesi amaçlanmış ve araştırma sosyal bilgiler dersi ile sınırlı tutulmuştur. $\mathrm{Bu}$ sınırlılığın aşılabilmesi için farklı derslere yönelik akademik risk alma ölçeklerinin geliştirilmesi önerilebilir.

\section{Kaynakça}

Ames, C. (1992). Achievement goals and classroom motivational climate. J. Meece ve D. Schunk (Ed.), Students' perceptions in the classroom içinde (327-348). Hillsdale, NJ: Erlbaum. 
Ames, C. ve Archer, J. (1988). Achievement goals in the classroom: Students' learning strategiesand motivation processes. Journal of Educational Psychology, 80(3), 260-267.

Anastasi, A. (1982). Psychological testing. New York: Mac Millan Publishing Co. Inc.

Bayram, N. (2009). Sosyal bilimlerde SPSS ile veri analizi. Bursa: Ezgi Kitabevi.

Beghetto, R. A. (2009). Correlates of intellectual risk taking in elementary school science. Journal of Research in Science Teaching, 46(2), 210-223.

Bentler, P. M. (1980). Multivariate analysis with latent variables: Causal modeling. Annual Review of Psychology, 31, 419-456.

Bentler, P. M. ve Bonett, D. G. (1980). Significance tests and goodness of fit in the analysis of covariance structures. Psychological Bulletin, 88, 588-606.

Braten, I. ve Stromso, H. I. (2004). Epistemological beliefs and implicit theories of intelligence as predictors of achievement goals. Contemporary Educational Psychology, 29(4), 371-388.

Brown, M. W. ve Cudeck, R. (1993). Alternative ways of assessing model fit. K. A. Bollen ve J. S. Long. (Eds.), Testing structural equation models içinde (136-162). Newbury Park, CA: Sage.

Büyüköztürk, Ş. (2010). Sosyal bilimler için veri analizi el kitabı. Ankara: Pegem Akademi Yayınları.

Byrne, B. ve Campbell, T. L. (1999). Cross-cultural comparisons and the presumption of equivalent measurement and theoretical structure: A Look Beneath the Surface. Journal of Cross- 
Cultural Psychology, 30(5), 555-574.

Byrnes, J. P. (1998). The nature and development of decision making: a self-regulation model. Mahwah, NJ: Lawrence Erlbaum.

Clifford, M. M., Lan, W. Y., Chou, F. C. ve Qi, Y. (1989). Academic risk taking: Developmental and cross-cultural observations. Journal of Experimental Education, 57, 321-338.

Clifford, M. M. ve Chou, F. (1991). Effects of pay off and task context on academic risk taking. Journal of Educational Psychology, 83, 499-507.

Clifford, M. M. (1988). Failure tolerance and academic risk taking in ten-to twelve-years-old students. British Journal of Educational Psychology, 58, 15-27.

Clifford, M. M. (1991). Risk taking: Theoretical, empirical and educational considerations. Educational Psychologist, 26, 263-297.

Costello, A. B. ve Osborne, J. W. (2005). Best practices in exploratory factor analysis: Four recommendations for getting the most from your analysis. Practical Assessment Research \& Evaluation, 10(7), 1-9.

Crocker, L. ve Algina, J. (1986). Introduction to classical and modern test theory. Fort Worth, TX: Holt, Rinehart and Winston Inc.

Cronbach, L. J. (1984). Essentials of psychological testing. New York: Harper Row.

Çiftçi, S. (2006). Sosyal bilgiler ögrretiminde proje tabanlı öğrenmenin ögrencilerin akademik risk alma düzeylerine, problem çözme becerilerine, erişilerine kalıcıliğa ve tutumlarına etkisi. Yayınlanmamış doktora tezi, Selçuk Üniversitesi. 
DeVellis, R. F. (2003). Scale development: Theory and applications. Newbury Park: Sage Publications.

Domino, G. ve Domino, M. L. (2006). Psychological testing: An introduction. Cambridge: Cambridge University Press.

Donovan, M. S. ve Bransford, J. D. (2005). How students learn: Science in the classroom. Washington: National Academies Press.

Dupeyrat, C. ve Mariné, C. (2005). Implicit theories of intelligence, goal orientation, cognitive engagement, and achievement: A test of Dweck's model with returning to school adults. Contemporary Educational Psychology, 30, 43-59.

Erkuş, A. (2012). Psikolojide ölçme ve ölçek geliştirme. Ankara: Pegem Akademi Yayınları.

Esen Kıran, B. (2005). Ergenlerde risk alma davranışı ile akademik başarının incelenmesi. Çukurova Üniversitesi Ĕ̈itim Fakültesi Dergisi, 2(29), 8-13.

Field, A. (2009). Discovering statics using SPSS. London: SAGE Publications.

Fraenkel, J. R., Wallend, N. E. ve Hyun, H. H. (2012). How to design and evaluate research in education. New York: McGraw Hill.

Gözen, G. (2013). Geçerlik. Ronald Jay Cohen ve Mark E. Swerdlik (Eds.), Psikolojik Test ve Değerleme içinde (172-207). (E. Tavşanc1l, Çev.). Ankara: Nobel.

House, D. J. (2002). An investigation of the effects of gender and academic self-efficacy on academic risk-taking for adolescent students. UMI ProQuest Digital Dissertations. Umi Number: 3066174. 
Hu, L. T. ve Bentler, P. M. (1999). Cutoff criteria for fit indexes in covariance structural analysis: Conventional criteria versus new alternatives. Structural Equation Modeling: A Multidisciplinary Journal, 6, 1-55.

İlhan, M. ve Çetin, B. (2013). Ortaokul öğrencilerinin matematik odaklı akademik risk alma davranışları: Bir ölçek geliştirme çalışması. E-uluslararası Eğitim Araştırmaları Dergisi, 4(2), 1-28.

İlhan, M., Çetin, B., Öner Sünkür, M. ve Yılmaz, F. (2013). Ders Çalışma Becerileri ile Akademik Risk Alma Arasındaki İlişkinin Kanonik Korelasyon ile İncelenmesi. Eğitim BilimleriAraştırmalarl Dergisi, 3(2), 123-146.

Kline, R. B. (2011). Principles and Practice of Structural Equation Modeling. New York: The Guilford Press.

Korkmaz, H. (2002). Fen ĕgitiminde proje tabanlı öğrenmenin yaratıc düşünme, problem çözme ve akademik risk alma düzeylerine etkisi. Yayınlanmamış doktora tezi, Hacettepe Üniversitesi.

Korkmaz, Ö. (2009). Eğitim fakültelerinin öğrencilerinin eleştirel düşünme eğilim ve düzeylerine etkisi. Türk Eğitim Bilimleri Dergisi, 7(4), 879-902.

Lawshe, C. H. (1975). A quantitative approach to content validity. Personnel Psychology, 28(4), 563-575.

Leech, N. L., Barlett, K. C. ve Morgan, G. A. (2005). SPSS for intermediate statistics; use and interpretation. Mahwah, NJ: Lawrence Erlbaum Associates.

Marsh, H. W., Hau, K. T., Artelt, C., Baumert, J. ve Peschar, J. L. (2006). OECD's brief self-report measure of educational psychology's most useful affective constructs: Cross-cultural, psychometric comparisons across 25 countries. International 
Journal of Testing, 6(4), 311-360.

Martin, C. R. ve Newell, R. J. (2004). Factor structure of the hospital anxiety and depression scale in individuals with facial disfigurement. Psychology Health and Medicine, 9(3), 327-336.

Meydan, H. C. ve Şeşen, H. (2011). Yapısal Eşitlik Modellemesi AMOS Uygulamaları. Ankara: Detay Yayıncılık.

Meyers, L. S., Gamst, G. ve Guarino, A. (2006). Applied multivariate research: Design and interpretation. Thousand Oaks, CA: Sage.

Muijs, D. (2004). Doing quantitative research in education with SPSS. London: SAGE Publications.

Neihart, M. (2010). Systematic risk-taking. Roeper Review, 21(4), 289-292.

Nunnally, J. ve Bernstein, I. (1994). Psychometric theory. New York: McGraw-Hill.

Öner Sünkür, M. (2013). Fen ve Teknoloji dersinde tahmin et-gözle-açıkla yöntemi ile desteklenmiş yansıtıcı düşünmeye dayalı etkinlik uygulamalarının değerlendirilmesi. Yayınlanmamış doktora tezi, İnönü Üniversitesi.

Öner Sünkür, M., İlhan, M., Kinay, İ. ve Kılınç, M. (2013). An examination of the relation between 8th grade students' level of academic risk taking and their positive and negative perfectionism traits. Çukurova University Faculty of Education Journal, 42(2), 01-10.

Özyılmaz Akamca, G. (2008). Ilköğretimde analojiler, kavram karikatürleri ve tahmin-gözlem-açıklama teknikleriyle desteklenmiş fen ve teknoloji ĕgitiminin ögrenme ürünlerine etkisi. 
Yayınlanmamış doktora tezi, Dokuz Eylül Üniversitesi.

Pallant, J. (2005). SPSS survival manual: A step by step guide to data analysis using SPSS for Windows. Australia: Australian Copyright.

Robinson, L. E. (2011). Academic risk-taking in an online environment. Yayınlanmamış doktora tezi, University of Connecticut.

Schermelleh-Engel, K. ve Moosbrugger, H. (2003). Evaluating the fit of structural equation models: tests of significance and descriptive goodness-of-fit measures. Methods of Psychological Research Online, 8(2), 23-74.

Schriesheim, C. A. ve Eisenbach, R. J. (1995). An exploratory and confirmatory factor analytic investigation of item wording effects on obtained factor structures of survey questionnaire measures. Journal of Management, 21(6), 1177-1193.

Sipahi, B., Yurtkoru, S. ve Çinko, M. (2010). Sosyal bilimlerde SPSS'le veri analizi. İstanbul: Beta Basım Yayım Dağıtım.

Skaar, N. R. (2009). Development of the adolescent exploratory and risk behavior rating scale. Yayınlanmamıs doktora tezi, Minnesota University.

Stangor, C. (2010). Research methods for the behavioral sciences. USA: Wadsworth.

Steiner, L. A. (2007). The effect of personal and epistemological beliefs on performance in a college developmental mathematics class. Yayınlanmamış doktora tezi, Kansas State University.

Strum, I. S. (1971). The relationship of creativity and academic risk-taking among fifth graders: Final report. ERIC Document Reproduction Service No: ED046212. 
Şeker, H. ve Gençdoğan, B. (2006). Psikolojide ve ĕgitimde ölçme aracı geliştirme. Ankara: Nobel Yayın Dağıtım.

Tavşancıl, E. (2010). Tutumların ölçülmesi ve SPSS ile veri analizi. Ankara: Nobel Yayın Dağıtım.

Tay, B., Özkan, D. ve Akyürek Tay, B. (2009). The effect of academic risk taking levels on the problem solving ability of gifted students. Procedia Social and Behavioral Sciences, 1(1), 1099-1104.

Taylor, M. E. (2010). Teaching efficacy, innovation, school culture and teacher risk taking. Yayınlanmamış doktora tezi, University of Louisville.

Tezbaşaran, A. (1997). Likert tipi ölçek hazırlama kılavuzu. Ankara: Türk Psikologlar Derneği.

Urbina, S. (2004). Essentials of psychological testing. New Jersey: John Wiley \& Sons. Inc.

Weston, R. ve Gore, P. A. (2006). A Brief Guide to Structural Equation Modeling. The Counseling Psychologist, 34(5), 719-751.

Yıldırım, K., Tay, B. ve Ateş, S. (5-7 Eylül 2007). Sınıf öğretmeni adaylarının akademik risk alma düzeylerini belirlemeye yönelik betimsel bir çalışma. 16. Ulusal Eğitim Bilimleri Kongresi, Gaziosmanpaşa Üniversitesi, Eğitim Fakültesi, Tokat. 